${ }^{1}$ См.: Ванданов Т.Б. Сопряжение норм международного права с достижениями научно-технической революции // Правоведение. 1990. №5. С. 96.

2 Всеобщая декларация прав человека 1948г. // Международное публичное право: С6. документов. Т. 1.М., 1996. С.460.

3 Собакина E.B. Международная коммуникация и международное право: современные тенденции // Советское государство и право. 1990. № 6. С.140.

4 Устав ООН 1945r. // Действуюшее международное право в 3 т. Т. 1. М., 1996. C. 12.

5 Лукашук И.И. Международное право: общая часть. М., 1996. С. 100.

${ }^{6}$ Гавердовский А.С. Имплементация норм международного права. Киев, 1980. C. 47-48.

7 Darrell Menthe, Jurisdiction in Cyberspace: A Theory of International Spaces. Aдpec в Интернете: www.law.umich.edu/menthe.html

${ }^{8}$ См.: Конвенция и Эксптуатационное соглашение о Международной организации морской спутниковой связи (ИНМАРСАТ). - М., 1981.

9 Бекяшев K.A. О6 итогах международной конференции ИМО по стандартам обучения, дипломированию и несению вахты персоналом рыболовньх судов // Московский журнал международного права. 1996. №1. С. 94.

10 Яиин С.В. В поисках дешевых рабочих рук // Морской флот. 1996. № 3. С. $29-30$.

Статья поступила в редакцию в марте 2000 года.

\title{
ИНСТИТУТ ГРАЖДАНСТВА СОЮЗА БЕЛАРУСИ И РОССИИ - ПРОБЛЕМЫ И ПЕРСПЕКТИВЫ
}

\author{
C.В. К о с и л к и н*
}

Вот уже более семи лет прошло со времени распада СССР зимой 1991 года. Процессы дезинтеграции за это время, как это сейчас принято говорить, на "пост-советском пространстве" зашли, пожалуй, много дальше, чем это можно было себе представить тогда. Вместо некогда единой системы - политической, экономической, социальной, образовалось несколько разобщенных комплексов. Каждое государствочлен СНГ сегодня, в полном соответствии с принципом суверенного равенства, который является нормой јus cogens (обычной, присущей лат.) международного права, само решает, идти ли к дальнейшей дезинтеграции, или, в соответствии с принципом сотрудничества, точно

\footnotetext{
*Сотрудник Международно-правового управления Министерства юстиции Российской Федерации.
} 
так же являюшимся јus cogens, развивать на новой основе процессы интеграции, исходя при этом из интересов своих народов.

Сегодня в СНГ активно обсуждается вопрос о разноскоростной, или многоуровневой интеграции. И если в этом процессе позволительно будет выделить авангард и арьергард, то к первому, безусловно, следует отнести Союз Беларуси и России.

Еще в 1996 году два государства - Беларусь и Россия решились на углубление интеграции в экономической и других сферах общественной жизни, и образовали Сообщество Беларуси и России. Однако, достигнутый уровень сближения показался недостаточным, и ровно через год после этого Сообщество, в соответствии с Договором от 2 апреля 1997 года, преобразуется в Союз Беларуси и России. 23 мая того же года подписывается Устав Союза, который, вместе с Договором, образует нормативно-правовую базу нового межгосударственного интеграционного образования.

Одним из кардинально новых положений, включенных в Устав Союза, стало введение гражданства Союза Беларуси и России.

Конечно же, это положение всколыхнуло множество противоречивых суждений - от самых негативных до однозначно положительных. Конечно же, в введении этой нормы велика политическая составляющая, и уже в силу этого ее можно по-разному оценивать. Однако, как бы ни была увлекательна полемика, следует все же помнить, что нормы Договора и Устава Союза являются, в соответствии с частью 4 статьи 15 Конституции Российской Федерации, составной частью ее правовой системы, а значит, - обязательны для исполнения. А раз так, - по-видимому, есть смысл подробнее проанализировать существо норм, касающихся гражданства Союза.

Прежде всего, следует остановить свое внимание на статье 2 Устава, прямо гласящей "Устанавливается гражданство Союза. Каждый гражданин Российской Федерации и каждый гражданин Республики Беларусь является одновременно гражданином Союза". Анализируя эти положения Устава, следует сразу обратить внимание на несколько моментов.

Прежде всего, необходимо отметить, что гражданство Союза устанавливается без оговорок, не как перспектива или цель, но постулируется как некая наличная правовая реальность. То есть предполагается, что с момента вступления в силу уставных документов Союза возникает некая устойчивая правовая связь между гражданином России и Беларуси, который с этого момента является гражданином Союза, и межтосударственным образованием - Союзом Беларуси и России. Признание существования такой правовой связи входит в противоречие с устоявшимися представлениями о том, что гражданство возможно только в государстве, в то время как Союз Беларуси и России государством не является. Однако, опыт введения гражданства в межгосударственном образовании все же существует не только в Союзе Беларуси и России - право Европейского Союза также знает этот институт. ${ }^{1}$ Более того, не будет ошибкой утверждать, что положения, касающиеся гражданства в Уставе Союза Беларуси и России во многом похожи на положения ст. 8 части 2 Договора о Европейском Союзе 1992 года. 
Важно также отметить, что статья 2 Устава, устанавливающая гражданство Союза, помешена в главу 1 "Принципы и цели Союза", что должно подчеркивать тот факт, что единое гражданство Союза - не второстепенное, а одно из важнейших положений в Уставе. Это - один из базовых принципов, на которых строится или, во всяком случае, должна строиться интеграция в Союзе.

Глава IV, состоящая из одной статьи 18, "Гражданство Союза" конкретизирует положения ст. 2 Устава.

В соответствии с частью первой ст. 18 Устава, наличие у гражданина Российской Федерации и гражданина Республики Беларусь гражданства Союза не умаляет его прав и свобод и не освобождает от обязанностей, вытекаюших из гражданства соответствуюшего государства-участника Союза. Таким образом, граждане Российской Федерации (как и граждане Республики Беларусь) гарантируются от ущемления или любого ограничения их конституционных, а также всех иных прав и свобод. Так, например, права, приобретенные российскими гражданами в связи со вступлением России в Совет Европы (например - на обращение в Европейский суд по правам человека), не могут быть ни в коей мере ограничены, несмотря на то, что граждане Беларуси таких прав не имеют. Это положение ст. 18, между прочим, вызывает ряд трудностей, преодолеть которые на основе Устава не представляется возможным. Прежде всего, сложность в том, что единое гражданство на сегодняшний день не обеспечено равными правовыми стандартами, в том числе в области прав и свобод человека.

Граждане России и Беларуси обладают различным объемом прав и свобод, что несколько обесценивает единое гражданство Союза. По-видимому, выход из этого возможен только один - постепенное сближение, гармонизация законодательств и скоординированная внешнеполитическая деятельность, в том числе - сотрудничество с международными организациями, для приближения к международным, в том числе - европейским, стандартам в области прав и свобод человека.

Часть вторая статьи 18 устанавливает, что наряду с правами и обязанностями, вытекаюшими из гражданства соответствуюшего государства-участника Союза, граждане Союза наделяются правами и исполняют обязанности, которые связаны с гражданством Союза. Систематически толкуя положения ст. 18, можно утверждать, что обязанности, вытекающие из гражданства государства-участника Союза, не могут противоречить обязанностям, вытекающим из гражданства Союза. Однако, Устав не содержит прямо определенных обязанностей гражданина Союза.

Что же касается прав граждан Союза, то они, в соответствии с частью. 3 статьи 18, таковы:

А) на свободное передвижение и постоянное проживание в пределах территории Российской Федерации и территории Республики Беларусь с соблюдением правил, установленных законами этих государств в отношении отдельных районов и местностей;

Б) на защиту на территории третьей страны, где нет представительства государства-участника Союза, гражданином которого он является, со стороны дипломатических представительств или консульских учреж- 
дений другого государства-участника Союза на тех же условиях, что и граждане этого государства;

В) на участие в управлении делами Союза;

Г) на владение, пользование и распоряжение имушеством на территории другого государства - участника Союза на тех же условиях, что и граждане этого государства.

Часть четвертая статьи 18 отдельно устанавливает, что гражданин Союза, постоянно проживаюший в другом государстве-участнике Союза, имеет право избирать и быть избранным в органы местного самоуправления на территории этого государства.

Остановимся чуть подробнее на предоставляемых гражданам Союза правах. Их можно разделить на несколько групп: права, связанные с предоставлением национального режима гражданам одного государства-учаотника Союза на территории другого государства, и права по отношению к Союзу как межгосударственному образованию. $\mathrm{K}$ первой группе можно отнести права на свободное передвижение и постоянное проживание, на жилье на территории третьей страны, на владение, пользование и распоряжение имуществом, и избирательные права - активное и пассивное, на уровне местного самоуправления.

Ко второй относится право на участие в управлении делами Союза. Предоставление национального режима гражданам одного государстваучастника Союза на территории другого оговаривается также и в других статьях Устава, в частности - пункт л) статьи 9.

Однако, надо сразу сказать, что национальный режим в Союзе имеет ряд особенностей.

Прежде всего, определимся, что в приниипе понимается под национальным режимом. Так, в Большом юридическом словаре (М., ИнфраM, 1998) дается такое определение национального режима: "Национальный режим - принцип, применяемый в международных договорах, в силу которого юридическим и физическим лицам одного государства предоставляются на территории другого государства такие же права,... какие предоставляются его собственным юридическим и физическим лицам. Национальный режим может быть установлен в законодательстве отдельных государств".

С этим определением можно согласиться, но при этом необходимо заметить, что конкретный объем прав, льгот и привилегий, предоставляемых иностранцам, в каждом государстве все же различный. Так, исходя из Конституции Российской Федерации и российского законодательство о правовом положении иностранцев, можно сделать вывод, что принцип национального режима действует в Российской Федерации по отношению ко всем иностранцам. Однако, в законодательстве государства, а применительно к России это - статья 160 основ гражданского законодательства 1991 года, могут устанавливаться и устанавливаются определенные изъятия в отношении предоставляемых иностранцам равных прав с отечественными гражданами. И если право на свободное передвижение и постоянное проживание, на владение, пользование и распоряжение имушеством предоставляется всем иностранцам, то право 
на зашиту на территории третьей страны, а также избирательные права на уровне местного самоуправления предоставляются только гражданам Союза. Таким образом, можно сказать, что в рамках Союза гражданам одного государства на территории другого предоставляется специальный национальный режим, с более широким объемом прав, чем для обычных иностранцев.

В данном контексте особенно хочется отметить предоставление гражданам одного государства на территории другого избирательных прав на уровне местного самоуправление. Для правовой сферы государств СНГ оно представляется очень интересной новацией. Прецедент такого предоставления существует в Европейском Союзе, но какой-то определенной, сложившейся практики не существует и там, а в наших государствах нет пока и достаточной регламентации этого вопроса. Думается, что если бы такая практика все же сложилась в Союзе Беларуси и России, это бы стало значительным, и притом реальным шагом на пути интеграции, стало бы надежным залогом жизнеспособности Союза.

Что же касается права граждан Союза на участие в управлении его делами, то пока ни в Уставе, ни где бы то ни было еще механизм такого участия не определен. С большими оговорками к участию в управлении делами Союза можно было бы отнести "всенародное обсуждение" проектов Уставных документов Союза, проводимое в России и Беларуси.

Сегодня еще трудно однозначно определить будущую судьбу Союза Беларуси и России, а значит - и единого гражданства. Пока это скорее политический институт. Впрочем, вполне возможно, что в скором времени единое гражданство станет объективной повседневной правовой реальностью. Конечно, для этого еще предстоит многое сделать, прежде всего - унифицировать правовой статус человека и гражданина, а для этого потребуются взаимные усилия, как в форме заключения договоров, так и в форме принятия унифицированных законодательных актов. Главное, чтобы деятельность по сближению правовых систем России и Беларуси была на пользу двух наших народов, на пользу граждан наших государств.

${ }^{1}$ См. об этом напр. Б.Н. Топорнин Европейское право. М., 1998, стр. 157.

Статья поступила в редакцию в июне 1999 z. 